\title{
İslami Bankalarda Kredi Riskini Belirleyen Faktörler: Panel Veri Analizi ile Türkiye'de Katılım Bankacilı̆ı Üzerine Ampirik Bir Uygulama
}

Nasıf ÖZKAN* - Gökhan IȘIL"

Makale Gönderim Tarihi: 22.12.2015

Makale Kabul Tarihi: 22.02.2016

\section{Öz}

Bu çalıșmada, Türkiye'de faaliyet gösteren dört katılım bankasının 2006 - 2014 yılları arası üç aylık verileri kullanılarak kredi risklerini belirleyen faktörler araștırılmaktadır. Kredi riski üzerinde bankaya özgü faktörlerden hangisinin anlamlı etkilerinin olduğunu göstermek için panel veri regresyon modeli kullanılmaktadır. Bulgular, katılım bankalarının geri ödenmeme riski tașıyan kredilere karșı ayırdıkları özel karșılıkların toplam varlıklar içindeki payının arttıkça, kredi risklerinin de artacağını göstermektedir. Diğer taraftan, kredilerin toplam varlıklar içindeki payının veya banka büyüklüğünün artması kredi riskinin azalmasına neden olmaktadır.

Anahtar Sözcükler: Kredi Riski, İslami Bankacılık, Katılım Bankacılığı, Panel Veri Analizi

Arș. Gör. Dr., Dumlupınar Üniversitesi, Uygulamalı Bilimler Yüksekokulu, Bankacılık ve Finans Bölümü, nasif.ozkan@dpu.edu.tr

** Yrd. Doç. Dr., Marmara Üniversitesi, Bankacılık ve Sigortacılık Yüksekokulu, Bankacılık Bölümü, gokhanisi@@marmara.edu.tr 


\section{The Determinants of Credit Risk in Islamic Banks: An Empirical Analysis on the Turkish Participation Banks with Panel Data Analysis}

\section{Abstract}

In this study, the determinants of bank credit risk are analyzedfor four participation banks that operate in Turkey, by using quarterly data set between 2006 and 2014.The findings of the study suggest that as the ratio of specific provisions in total assets increases, the credit risk shall also increase. Conversely, the increase of the ratio of loans in total assets, or the increase of the participation banks' size, results in lower credit risk for the participating banks.

Keywords: Credit Risk, Islamic Banking, Participation Banking, Panel Data Analysis

\section{GiRiș}

Geleneksel ve İslami bankacılık uygulamalarının birlikte yer aldığı Türkiye bankacılık sistemi içinde faaliyet gösteren bankalar bir takım risklerle karșı karșıyadır. Bu risklerden bazıları kredi riski, likidite riski, operasyonel risk ve piyasa riski olarak sıralanabilir. Kredi riski, genel olarak bankaların kredi alacaklarının tahsilatını zamanında veya tam olarak gerçekleștirememeleri sonucunda ortaya çıkmaktadır (Yaslıdağ,2007). Geleneksel kredi yaklașımına göre bankalar iyi bir istihbarat yaparak tahsil edebilme olasılığı yüksek olan kredileri vermeli ve kredilerin miktarıyla orantılı olarak müșterilerinden teminat talep etmelidir. Kredilerin tahsilatının zamanında veya tam olarak yapılamaması kredi riskinin artmasının yanında bankaların karlılıklarını da doğrudan etkilemektedir (Colquitt, 2007). Özellikle ekonomik daralma veya kriz dönemlerinde bankalar, kredilerinin tahsilinde sorunlar yașayabilmektedir. Dolayısıyla bu dönemlerde bankaların kredi riski yükselebilmektedir. Ayrıca bu dönemlerde, büyük ölçekli bankaların kredi hacimleri, küçük ölçekli bankalara göre daha büyük olacağından; büyük ölçekli bankaların kredi riskiyle karșılașma olasılıkları da küçük 
ölçekli bankalara göre daha yüksek olabilmektedir.(Oktay ve Temel, 2007)

Literatürde geleneksel ve İslami bankaların kredi riskini etkileyen faktörleri araștıran birçok çalıșma yapılmaktadır. Bu çalıșmalarda, bankaların kredi riskleri üzerinde, bankaya özgü (içsel) ve/veya makroekonomik (dıșsal) faktörlerin etkili olabileceği belirtilmektedir. Ayrıca çalıșmalarda, hangi banka türünün krizlere karșı daha dayanıklı ya da daha düșük kredi riskine sahip olduğu da tartıșılmakładır. Bu bağlamda çalıșmada, Türkiye bankacılık sektöründe faaliyette bulunan katılım bankalarının kredi riskini belirleyen bankaya özgü faktörler, bankaların 2006-2014 yılları arasındaki üç aylık verileri kullanılarak panel veri regresyon modeli yardımıyla tahmin edilmeye çalıșılmaktadır.

Çalıșma yedi bölümden olușmaktadır. Giriș bölümünü takip eden ikinci bölümde, Türkiye'de katılım bankacılığının gelișiminden; üçüncü bölümde ise, İslami bankalarda kredi riskiyle ilgili yapılan literatür çalıșmalarından bahsedilmektedir. Dördüncü bölümde, çalıșmada uygulanan metodoloji; beșinci bölümde, çalıșmada kullanılan veri ve değișkenler açıklanmaktadır. Alııncı bölümde, ampirik bulgular yorumlanmakta ve son bölümde ise, çalıșmanın sonuçları özetlenmektedir.

\section{Türkiye'de Katılım Bankacılığının Gelișimi}

Günümüzde İslam ülkeleri dıșında da yoğun olarak kullanılan İslami finans uygulamalarııın doğușu M.Ö. 2000'li yıllara kadar dayanmaktadır. Ancak İslam ülkelerinde, İslami finans uygulamalarının yaygınlık kazanması, bu ülkelerde 20. yüzyılda artan sanayileșme hızı ve 1973 petrol kriziyle artan petrol fiyatlarının sebep olduğu hızlı büyüme oranları sonrasında gerçekleșmiștir. Özellikle 1975 yılında İslam Kalkınma Bankası'nın kurulmasıyla birlikte İslam ülkelerinde geleneksel bankacılı̆ı̆ın yerini İslami bankacilık uygulamaları almaya bașlamıștır (Polat, 2009). İslam Kalkınma Bankası'nın ìslam ülkelerindeki ekonomik ve finansal gelișmenin gerektirdiği ihtiyaçları tam olarak karșılayamaması, Isviçre'de 1981 yılında "Dar Al Maar Al Islâmi" isimli bir holdingin kurulmasına neden olmuștur. Bu holdingin kuruluș amacı, İslami 
kurallara uygun olarak hizmet veren finansal kurumlara dört kıtada önderlik ve destek vermektir. Holdingin kurulduğu yıldan sonra hızla büyümeye bașlayan İslami bankacilık uygulamaları, sadece İslam ülkelerinde değil diğer ülkelerde de sıklıkla kullanılmaya bașlanmıștır (Türker, 2010).

Türkiye'de 1980'li yıllarda bașlayan finansal serbestleșme politikalarıyla birlikte İslami bankacılık sisteminin hazırlıklarına bașlanmıștır. 16.12.1983 tarih 83/7506 sayılı kararnameyle Türkiye'de kurulacak özel finans kurumlarının temeli atılmıștır. 1985 yılında Albaraka Türk Özel Finans Kurumu A.Ș. bankasının kurulmasıyla bașlayan özel finans kurumları sistemi, 1996 yılında yedi bankaya ulașmıștır. Kasım 2000 ve Șubat 2001 yıllarında yașanan likidite krizine kadar özel finans kurumları içinbir güvence sistemi olușturulmamıștır. Yașanan bu krizler sonrasında, Türkiye'de özel finans kurumları için de bir güvence sistemine ihtiyaç duyulduğu ortaya çıkmıștır. Bankalar kanununda yapılan değișiklikle, Özel Finans Kurumları Birliği kurulmuș ve güvence fonuyla șahsi sorumluluk müessesi olușturulmuștur. 1 Kasım 2005 tarihinde yürürlüğe giren 5411 sayılı Bankacılık Kanunu'yla özel finans kurumları,katılım bankalarına dönüștürülmüștür.

Türkiye'de 2015 yılı Aralık ayı itibarıyla beș katılım bankası faaliyet göstermektedir (Albaraka Türk, Bank Asya, Kuveył Türk, Türkiye Finans ve Ziraat Katılım). Bu beș katılım bankasından, Ziraat Katılım "kamusal sermayeli", Bank Asya "yerli sermayeli", Albaraka Türk, Kuveyt Türk ve Türkiye Finans ise," yabancı sermayeli" katılım bankasıdır. Bu bankalardan Ziraat Katılım, 2015 yılı Mayıs ayı içinde faaliyete geçmiș; Bank Asya ise, aynı tarihlerde Tasarruf Mevduatı Sigorta Fonu'na (TMSF) devredilmiștir. 2014 yılsonu rakamlarına göre, dört katılım bankasının toplam aktifleri 104, 1 milyar TL, kullandırdığı fonlar 70,0 milyar TL, topladığı fonlar 66,8 milyar TL ve özkaynakları 9,3 milyar TL civarındadır. Katılım bankalarının, bu rakamlar ile Türkiye bankacılık sektöründen aldığı paylar sırasıyla \%5,2; \%5,4; \%6,2 ve \%4, 1'dir. Aynı yılda katılım bankaları, 990 șubede 16.270 kiși ile hizmet vermektedir (TKBB, 2014). Katılım bankalarının Türkiye bankacılık sektörü için- 
deki payı düșük olsa da birçok uzman tarafından gelecek yıllarda bu payın giderek artması beklenmektedir.

\section{Literatür Taraması}

Banka kredileri șirketler için önemli bir finansman kaynağıdır. Bu nedenle bankalar șirketlere finansman sağlama faaliyetini gerçekleștirirken bir takım risklere maruz kalmaktadır. Bu risklerin en önemlilerinden biri de kredi riskidir. Literatürde bankaların maruz kaldıkları kredi riskini etkileyen faktörleri araștıran birçok çalıșma bulunmaktadır. Yapılan bu çalıșmaların daha çok geleneksel bankalara yoğunlaștığı görülmektedir (Ahmad ve Ariff, 2007; Angbazo, 1997; Berger ve De Young, 1997; Cebenoyan ve Strahan, 2004). Ancak son yıllarda, sadece İslami bankalarda ya da her iki bankacılık türünde kredi riskini belirleyen faktörleri karșılaștırmalı olarak inceleyen çalıșmalar da yapılmaktadır. Bu çalıșmada, İslami bankalarla ilgili yapılan çalıșmalara değinilmektedir.

Bankaların kredi riskleri üzerinde bankaya özgü ya da makroekonomik faktörler etkili olabilmektedir. Ahmad ve Ahmad (2004) tarafindan yapılan çalıșmada,Malezya İslami bankalarının kredi riskini etkileyen bankaya özgü faktörlerin; bankaların toplam aktif büyüklüğü, risk ağırlıklı varlıkları ve yönetim etkinliği olduğu ifade edilmektedir. Diğer taraftan yazarlar, Malezya'da faaliyet gösteren geleneksel bankaların kredi riskinin ise;riskli sektörlere verilen krediler, sermaye düzenlemeleri, kredi karșılıkları ve risk ağırlıklı aktifler gibi faktörlerden etkilendiğini belirtmektedir. How ve diğerleri (2005), Malezya'da İslami krediler sunan ticari bankaların toplam aktif büyüklüğü ile kredi riski arasında negatif bir ilișki olduğunu ileri sürmektedir. Diğer taraftan Ahmed ve diğerleri (2011), Pakistan'da faaliyet gösteren İslami bankaların toplam aktiflerinin büyüdükçe, maruz kaldıkları kredi risklerinin de artacağını vurgulamaktadır. Ayrıca yazarlar, Pakistan İslami bankalarının kredi riskinin sermaye yeterliliği rasyosundan negatif yönde etkilendiğini ifade etmektedir. Abedifar ve diğerleri (2013) de, 24 ülkeden toplam 553 İslami ve geleneksel bankayı ele aldığı çalıșmasında, Müslüman nüfusun yoğun olduğu ülkelerde kurulmuș küçük İslami bankaların, geleneksel bankalara göre daha 
düșük kredi riskine sahip olduğunu belirtmektedir. Misman ve diğerleri (2013), Malezya İslami bankalarının kredi riski düzeylerini, kredi kalitesi ve sermaye tamponunun pozitif; sermaye rasyosu ve kredi genișlemesinin ise, negatif yönde etkilediğini göstermektedir. Körfez Arap Ülkeleri İșbirliği Konseyi'ne (Gulf Cooperation Council - GCC) mensup alıı ülkede makroekonomik değișkelerin kredi riski üzerindeki etkisini inceleyen Al-Wesabi ve Ahmad (2013) ise, kredi riskiyle gayri safi yurtiçi hasıla arasında istatistiksel olarak anlamlı negatif bir ilișki olduğunu ifade etmektedir. Diğer taraftan yazarlar, enflasyon ve faiz oranının kredi riskiyle ilișkili olmadığını ortaya koymaktadır. Ayrıca çalıșmada, kaldıraç oranı ve likiditenin de İslami bankaların kredi riskini belirleyen bankaya özgü faktörler olduğu sonucuna ulașılmıștır. Nursechafia (2014) ise, makroekonomik değișkenlerin Endonezya'da faaliyet gösteren İslami bankaların kredi riskini belirleyip belirlemediğini incelemekte ve bankaların kredi riskiyle döviz kuru, enflasyon ve ekonomik büyüme oranı arasında negatif; para arzı ve İslami bankalararası para piyasası faiz oranı arasında pozitif yönlü bir ilișki olduğu göstermektedir.

Literatürde İslami bankalar tarafından kullandırılan farkIı kredi türlerinin,bankaların kredi riski üzerinde farklı etkilerinin olduğunu ileri süren çalıșmalarda söz konusudur. İslami bankalar temel olarak müșterilerine özkaynağa dayalı, ticarete dayalı ve desteğe dayalı olmak üzere üç tür kredi sözleșmesi kullandırmaktadır (Misman ve diğerleri, 2013). Khan ve Ahmed (2001)'e göre,özkaynağa dayalı Mudaraba ve Mușaraka sözleșmelerinin daha yüksek kredi riskine sahip olmaları beklenmektedir. Ahmed ve Khan (2007) tarafından 18 bankacı üzerinde yapılan çalıșmada ise, mușaraka sözleșmesinin en yüksek;mudaraba sözleșmesinin ise, en düșük kredi riskine sahip sözleșme olduğu kanısına varılmıștır. Ayrıca çalıșmalarda, özkaynağa dayalı kredi sözleșmelerinin, ticarete dayalı kredi sözleșmelerine göre daha riskli oldukları vurgulanmaktadır (Misman ve diğerleri, 2013). Rahman ve Shahimi (2010) ise, İslami bankalar tarafından sunulan gayrimenkul kredilerinin ve bankaların kredi yapılarındaki istikrarın kredi riskleri üzerinde etkili olduğunu ileri sürmektedir. Ancak yazarlar, analize makroekonomik değișkenlerin ilave edilmesiyle yukarıda 
bahsedilen faktörlerin anlamlı etkilerinin ortadan kaybolduğunu göstermektedir.

2008 küresel finans krizinin geleneksel ve İslami bankalarının kredi riski yönetimi üzerindeki etkilerini inceleyen Ali ve Ghauri (2013), Pakistan İslami bankalarının kredi riskinin krizden etkilenmekle birlikte, bu bankaların geleneksel bankalara göre krize karșı daha dayanaklı olduklarını göstermektedir. Yazarlar bu durumun, İslami bankaların faaliyetlerinde șeffaf olmalarından ve çalıșma ilkelerine bağlı kalmalarından kaynaklandığını ileri sürmektedir. 28 ülkeden toplam 209 İslami ve geleneksel bankanın küresel finans krizi döneminde kredi riski düzeylerini inceleyen Fehri ve Chkoundali (2015), birçok geleneksel bankanın İslami bankalara göre daha yüksek kredi riskine sahip olduğunu bulmuștur. Yazarlara göre, geleneksel bankaların yüksek kredi riski düzeyleride dünyada finansal krizlere neden olabilmektedir.

Literatürde İslami bankacılık sistemiyle geleneksel bankacılık sisteminin kredi risklerini karșılaștıran çalıșmalara göre (Masood ve diğerleri, 2012; Nurul ve diğerleri, 2015),genel olarak İslami bankalar, geleneksel bankalardan daha düșük kredi riskine maruz kalmaktadır. Masood ve diğerleri (2012), Birleșik Arap Emirlikleri İslami bankalarının, bu ülkede faaliyet gösteren İslami olmayan bankalara göre daha yeni ve gelișmiș kredi riski yönetim tekniklerini kullandıklarını belirtmektedir. Ayrıca yazarlar, İslami bankaların kredi riskinin yönetimiyle ilgili son çıkan teknikleri hemen benimsediklerini ve bu bankaların kredi riski yönetim tekniklerinin ilerleyen yıllarda daha da gelișeceğini ileri sürmektedir. Nurul ve diğerleri (2015) ise, kredi riskinin ölçülmesinde kullanılan tekniklerin, hangi bankacılık sisteminin daha düșük kredi riskine sahip olduğunun karar verilmesinde önemli bir rol oynadığını göstermektedir.

\section{Metodoloji}

Çalıșmada, panel veri regresyon yöntemi kullanılarak katılım bankalarının kredi riskini belirleyen faktörler ampirik açıdan tespit edilmeye çalıșılmaktadır. Panel veri regresyon analizine bașlamadan önce değișkenler arasındaki sahte ilișkilerin, ampirik bulguları 
etkilemesini önlemek için değișkenlerin durağan olup olmadıkları panel birim kök testleri yardımıyla araștırılmaktadır. Çalıșmada ortak birim kök süreçlerini araștıran Levin ve diğerleri (2002) testi, her birim (banka) için birim kök sürecini araștıran Im ve diğerleri (2003) testi ile birimlerden bağımsız serilerde durağanlığı araștıran Genelleștirilmiș Dickey Fuller birim kök testi kullanılmaktadır. $\mathrm{Bu}$ testlerde $\mathrm{H}_{0}$ hipotezi serilerin birim kök içerdiğini; $\mathrm{H}_{1}$ alternatif hipotezi ise, serilerin birim kök içermediğini ileri sürmektedir (Çelik ve Akarım, 2012; Korkmaz ve diğerleri, 2010).

Panel veri regresyon analizinde sabit etkiler modeli tercih edilmiștir ${ }^{1}$ Sabit etkiler modeli, eğim katsayılarının sabit olduğunun varsayıldığı, birimler arasındaki farklılıkları sabit terimdeki farklılıklarla açıklamaya çalıșan ve yatay kesit verilerin tesadüfi bir örneklemden elde edilmediği bir durumu ifade eden modellere denilmektedir. Bu modellerde tek yönlü ve iki yönlü sabit etkilerin varlığının testi için üç farklı hipotez kurulmaktadır. İlk olarak, iki yönlü sabit etkilerin varlığı $\mathrm{H}_{1}: \mu=0, \lambda=0$ hipoteziile test edilmektedir. $H_{1}$ hipotezinde $\mu$ iki yönlü modelde yatay kesit etkisini, $\lambda$ ise zaman etkisini temsil etmektedir. $H_{1}$ hipotezinin reddedilemediği durumlarda, modele sabit etkinin dahil edilmesine gerek olmadığına karar verilmektedir. $\mathrm{H}_{1}$ hipotezinin reddedilmesi durumunda ise, $\mathrm{H}_{2}: \mu=0 \mid \lambda \neq 0$ ve $\mathrm{H}_{3}: \lambda=0 \mid \mu \neq 0$ tek yönlü hipotezlerinin test edilmesi gerekmektedir. Hata terimlerinde sabit etkinin var olup olmadığı $\mathrm{F}_{\mathrm{O} \text { ss }}$ istatistiğinin hesaplanması ile test edilmektedir (Erlat, 2011).

$F_{\text {OLS }}=\left(\frac{\left(R \widehat{\beta}_{O L S, U}^{*}-r\right)^{\prime}\left[R\left(X^{*} X^{*}\right)^{-1} R^{\prime}\right]^{-1}\left(R \widehat{\beta}_{O L S, U}^{*}-r\right)}{S_{O L S, U}}\right)\left(\frac{d f}{p}\right)=\left(\frac{S_{O L S, R}-S_{O L S, U}}{S_{O L S, U}}\right)\left(\frac{d f}{p}\right)$

Yıldız ve diğerleri (2009), panel veri analizinde kullanılan ișletmelerin gösterdikleri özellikler bakımından birbirlerine benzemeleri durumunda sabit etkiler regresyonunun tercih edilebileceğini belirtmektedir. Ayrıca Yerdelen Tatoğlu (2012), panel veri analizinde yatay kesit boyutun (bankalar) spesifik bir veri seti olması halinde sabit etkileri düșünmenin mantıklı olabileceğini vurgulamaktadır. Bu çalıșmada kullanılan veriler Türkiye bankacılık sektöründe faaliyet gösteren dört katılım bankasına aittir. 
Model (1)'de $\quad \mathrm{df}=\mathrm{T}-\mathrm{K}, \quad \mathrm{S}_{\mathrm{OLL}, \mathrm{R}}=\hat{\mathrm{u}}_{\mathrm{OLS} S, \mathrm{R}}{ }^{\prime} \hat{\mathrm{u}}_{\mathrm{OLS}, \mathrm{R}} \quad$ ve $S_{\text {OLS }, U}=\hat{u}_{\text {OLS U U }}$ ' $\hat{u}_{\text {OLS UU }}$ ve " $U$ " $\beta^{*}$ ve $\sigma^{2}$ nin kIsitlanmamıș, " $R^{\prime \prime}$ ise $\beta^{*}$ ve $\sigma^{2}$ nin kısıtlanmıș tahminlerini ifade etmektedir. Normallik varsayımı altında $\mathrm{F}_{\mathrm{OLS}}, \mathrm{F}_{\mathrm{p}, \mathrm{T}-\mathrm{K}}$ dağılımı göstermektedir.

Panel veri modellerinde en çok karșılașılan sorunlardan birisi hatalarda değișen varyans problemidir. Değișen varyans probleminin varlığını test etmek için Lagrange çarpanı (Lagrange Multiplier - LM) istatistiği hesaplanmakta ve $\chi_{\mathrm{k}}^{2}$ kritik değeri ile karșılaștırılmaktadır. Bu bağlamda, $\mathrm{H}_{0}: \sigma_{\mathrm{u} 1}^{2}=\cdots=\sigma_{\mathrm{uN}}^{2}$ ve $\mathrm{H}_{1}:$ En az biri $\sigma_{\mathrm{ui}}^{2} \neq \sigma_{\mathrm{uj}}^{2}$ hipotezleri test edilmektedir. $L M$ istatistiği ise așağıdaki gibi hesaplanmaktadır (Erlat, 2011).

$$
\mathrm{LM}_{\mathrm{h}}=\frac{\mathrm{T}}{2} \sum_{\mathrm{i}=1}^{\mathrm{N}}\left[\frac{\hat{\sigma}_{\mathrm{ui}}^{2}}{\hat{\sigma}_{\mathrm{u}}^{2}}-1\right]^{2}
$$

Burada, $\hat{\sigma}_{\mathrm{ui}}^{2}=\sum_{\mathrm{t}=1}^{\mathrm{T}} \mathrm{u}_{\mathrm{it}}^{2} / \mathrm{T} \quad$ ve $\hat{\sigma}_{\mathrm{u}}^{2}=\sum_{\mathrm{i}=1}^{\mathrm{N}} \sum_{\mathrm{t}=1}^{\mathrm{T}} \mathrm{u}_{\mathrm{it}}^{2} / \mathrm{NT}=\sum_{\mathrm{i}=1}^{\mathrm{N}} \hat{\sigma}_{\mathrm{ui}}^{2} / \mathrm{N} . \quad L M$ istatistiğinin küçük değerlere sahip olması durumunda, sabit varyansın varlığını ifade eden $\mathrm{H}_{0}$ hipotezi reddedilememektedir. Bir bașka ifadeyle bağımsız değișkenlerin sabit varyansa sahip olduğu kabul edilmektedir. $\mathrm{H}_{0}$ hipotezinin reddedilip modelde değișen varyans probleminin varlı̆ı̆ tespit edilirse, problem White (1980)'nin değișen varyansa uyumlu kovaryans matris tahmincisi kullanılarak giderilmektedir (Wooldridge, 2002; Greene, 2003; Griffiths ve diğerleri, 2012).

Kredi riski ile bu riskin belirleyicileri arasındaki ilișkinin varlığını analiz edebilmek için Berger ve De Young (1997), Angbazo (1997), Ahmad ve Ariff (2007) ve Misman ve diğerleri (2013)'ün gösterdiği așağıdaki lineer fonksiyon temel alınmaktadır.

$$
\mathrm{KR}=\mathrm{f}(\mathrm{x}, \mathrm{u})
$$

Model (3)'te KR, kredi riskini; $x$, kredi riski üzerinde etkisi olduğu düșünülen bankaya özgü değișkenler vektörünü ifade etmektedir. $u$ ise, kredi riskini etkileme ihtimali olan diğer değișkenlere (makroekonomik faktörler gibi) ilișkin hata terimini temsil etmektedir. Katılım bankalarının kredi riskini etkileyen bankaya özgü faktörleri içine alan Model (3) temel alındığında, çalıșmanın 
ampirik analizlerinde kullanılmak üzere așağıdaki panel veri regresyon modeli olușturulmuștur.

$$
\begin{gathered}
\mathrm{KR}_{\mathrm{it}}=\beta_{0}+\beta_{1} \mathrm{KTV}_{\mathrm{it}}+\beta_{2} \mathrm{KRKTV}_{\mathrm{it}}+\beta_{3} \mathrm{ÖTV}_{\mathrm{it}}+\beta_{4} \mathrm{SYR}_{\mathrm{it}}+\beta_{5} \mathrm{NKPGTV}_{\mathrm{it}}+\beta_{6} \mathrm{GGVTV}_{\mathrm{it}} \\
+\beta_{7} \mathrm{LNTV}_{\text {it }}+\varepsilon_{\text {it }}
\end{gathered}
$$

Model (4)'te alt indislerden " $i$ " yatay kesitleri bir bașka ifadeyle bankaları, " $\mathrm{t}$ " ise zaman boyutunu yani yılları temsil etmektedir. Ayrıca, $\beta_{0}$ sabit kesișim katsayısını, $\beta_{1}{ }^{\prime}$ den $\beta_{7}{ }^{\prime}$ ye kadar olan katsayılar bağımsız değișkenlere ilișkin eğim katsayılarını ve $\beta_{\text {it }}$ hata terimini göstermektedir. Model (4)'te yer alan değișkenlere ilișkin tanımlar Tablo 1'deaçıklanmaktadır.

\section{Veri Seti ve Değișkenlerin Tanımlanması}

Çalıșmanın örneklemi, Türkiye'de 2006-2014 yılları arasında faaliyet gösteren dört katılım bankasının dengeli panel verisinden olușmaktadır². Çalıșmada katılım bankalarının, üç aylık finansal tablo verileri kullanılmaktadır. Toplam örneklem büyüklüğü 144 banka yılı gözlemdir. Temel veri kaynağı, TKBB internet sitesinde yer alan istatistiki raporlardır ${ }^{3}$.

Çalıșmanın bağımlı değișkeni kredi riskidir. Kredi riski (KR) birçok çalıșmada olduğu gibi (Ahmad ve Ariff, 2007; Berger ve De Young, 1997; Fiordelisi ve Diğerleri, 2001; Misman ve diğerleri, 2013) takipteki krediler kaleminin toplam krediler kalemine oranlanması ile ölçülmektedir. Kredi riski üzerinde etkisi olduğu düșünülen bağımsız değișkenler ise, İlami bankalarda kredi riskini etkileyen faktörleri inceleyen çalıșmalar (Ahmad ve Ahmad, 2004; Ali ve Ghauri, 2013; Misman ve diğerleri, 2013) göz önünde bulundurularak bankaya özgü çeșitli faktörlerden olușmaktadır. Kredi riski üzerinde etkisi olduğu düșünülen bankaya özgü değișkeneler ise șunlardır: KTV (Toplam Krediler/Toplam Varlık-

2 Örneklem kapsamına dahil edilen bankalar; Albaraka Türk, Bank Asya, Kuveył Türk ve Türkiye Finans'tır.

3 Bank Asya'nın Aralık 2014'e ilișkin verileri, Kamuyu Aydınlatma Platformu (KAP) internet sitesinden alınmıștır. 
lar), KRKTV (Özel Karșilıklar/Toplam Varlıklar), ÖTV (Özsermaye/Toplam Varlıklar), SYR (Sermaye Yeterliliği Standart Oranı) ${ }^{4}$, NKPGTV (Net Kar Payı Geliri5/Toplam Varlıklar), GGVTV (Gelir Getiren Varlıklar'/Toplam Varlıklar) ve LNTV (Toplam Varlıkların Doğal Logaritması). Bu değișkenlere ilișkin semboller, tanımlar ve bağımsız değișkenlerin bağımlı değișken üzerindeki beklenen etkileri Tablo 1'de gösterilmektedir. Tablo 1'e göre KR bağımlı değișkeninin, KTV ve KRKTV bağımsız değișkenlerinden pozitif; ÖTV, SYR, GGVTV ve LNTV bağımsız değișkenlerinden ise negatif yönde etkilenmesi beklenmektedir. Diğer taraftan NKPGTV bağımsız değișkeni, KR bağımlı değișkenini pozitif ya da negatif yönde etkileyebilmektedir (Ahmad ve Ahmad, 2004; Misman ve diğerleri, 2013).

4 Sermaye yeterliliği standart oranının, incelenen dönemde üç farklı yöntemle hesaplandığı görülmektedir:

I. 2006 Mart -2006 Eylül => SYR= Özkaynak/(RAV+PRET)* 100

RAV: Toplam risk ağırlıklı varlıklar

PRET: Piyasa riskine esas tutar

II. 2006 Aralık -2012 Haziran => SYR= Özkaynak $/\left(\right.$ KRET+PRET+ORET) ${ }^{*} 100$

KRET: Kredi riskine esas tutar

PRET: Piyasa riskine esas tutar

ORET: Operasyonel riske esas tutar

III. 2012 Eylül - 2014 Aralık => SYR= Özkaynak/((KRSY+PRSY+ORSY)*12,5)* 100

KRSY: Kredi riski için gerekli sermaye yükümlülüğü (Kredi Riskine Esas Tutar*0,08) PRSY: Piyasa riski için gerekli sermaye yükümlülüğü

ORSY: Operasyonel risk için gerekli sermaye yükümlülüğü

5 Katılım bankalarının gelir tablosunda yer alan "Kar Payı Gelirleri" kalemi ile "Kar Payı Giderleri" kaleminin arasındaki farka eșittir.

6 Gelir getiren varlıklar, katılım bankalarının finansal durum tablolarının aktifinde yer alan krediler ve alacaklar, alım satım amaçlı finansal varlıklar, satılmaya hazır finansal varlıklar ve vadeye kadar elde tutulacak yatırımlar kalemlerinin toplamından olușmaktadır (Tunay ve Silpar, 2006). 


\section{Tablo 1: Değișken Tanımları}

\begin{tabular}{|c|c|c|}
\hline Değișkenler & Tanımlar & Beklenen Etki \\
\hline \multicolumn{3}{|c|}{ Bağımlı Değișken } \\
\hline KR & Takipteki Krediler/Toplam Krediler & \\
\hline \multicolumn{3}{|c|}{ Bağımsız Değișkenler } \\
\hline KTV & Toplam Krediler/Toplam Varlıklar & + \\
\hline KRKTV & Özel Karșılıklar/ Toplam Varlıklar & + \\
\hline ÖTV & Özsermaye/Toplam Varlıklar & - \\
\hline SYR & Sermaye Yeterliliği Standart Oranı & - \\
\hline NKPGTV & Net Kar Payı Geliri/Toplam Varlıklar & $+/-$ \\
\hline GGVTV & Gelir Getiren Varlıklar/Toplam Varlıklar & - \\
\hline LNTV & Toplam Varlıkların Doğal Logaritması & - \\
\hline
\end{tabular}

Katılım bankalarına ilișkin değișken verileri, TKBB tarafından Türkiye' de faaliyette bulunan katılım bankaları için hazırlanmıș istatistiki raporlardan elde edilmiștir.

Çalıșmada kullanılan değișkenlere ilișkin tanımlayıcı istatistiki bilgiler Tablo 2' de sunulmaktadır. Tablo 2 Panel A örnekleme ilișkin istatistikleri, Tablo 2 Panel B ise, değișkenlerin yıllar itibariyle ortalama değerlerini göstermektedir. Tablo 2 Panel A'da ortalama KR değeri, takipteki kredilerin toplam krediler içindeki payının \%3,9 olduğunu göstermektedir. Așırı uç gözlemlerin (outliers) analize etkisini azalłmak için bağımlı ve bağımsız değișkenler $\% 1$ düzeyinde winsorize edilmektedir ${ }^{7}$ (Cebenoyan ve Strahan, 2004; Cornett ve diğerleri, 2011 1).Bu sonuç, örnekleme dahil edilen katıım bankalarının incelenen dönemde kullandırdıkları yüz krediden dördünün geri ödenme süresi içinde sorunsuz bir șekilde bankaya geri ödenmediğini ifade etmektedir. Ortalama KTV değeri, toplam varlıkların yaklașık \%73'üdür. Bir bașka ifadeyle kredi riskiyle ilișkili önemli bir kalem olan krediler, toplam varlıkların \%73'ünü olușturmaktadır. Kredi riski tașıyan kredilere karșı ayrılan özel karșılıkların toplam varlıklar içindeki payı ise \% 1,7 civarındadır. ÖTV'nin ortalama değeri \% 1 1,4'tür. SYR ortalama değeri \%14,8, minimum değeri \%11,5, maksimum değeri \%22,3'tür. SYR'nin ortalaması, incelenen dönemde Basel II Kriterleri'nin (\%8)

7 Winsorize ișlemi, N'inci yüzdenin altında kalan verilerin $N^{\prime}$ 'inci veri ile değiștirilmesinden olușmaktadır. Diğer bir ifadeyle \%1'lik bir winsorize ișlemi, \%1 düzeyinin alında kalan verilerin \% 1'inci veri ile değiștirilmesi anlamına gelmektedir. 
üstünde seyretmektedir. NKPGTV'nin ortalama değeri \%2,8'dir. GGVTV'nin ortalama değeri ise, \%75,5'tir. Gelir getiren varlıklar içinde en büyük paya krediler kalemi sahiptir. Kredilerin toplam varlıkların \%73'ünü olușturduğu düșünülürse, diğer gelir getiren varlıklar olan finansal varlıkların ve yatırımların katılım bankaları bilançolarında küçük bir paya sahip olduğu görülmektedir.

\section{Tablo 2: Tanımlayıcı İstatistikler}

\begin{tabular}{|c|c|c|c|c|c|c|c|c|c|}
\hline \multicolumn{10}{|c|}{ Panel A: Örneklem Istatistikleri } \\
\hline Değișkenler & \multicolumn{2}{|c|}{ Ortalama } & \multicolumn{2}{|c|}{ Std. Sapma } & \multicolumn{2}{|c|}{ Medyan } & \multicolumn{2}{|c|}{ Minimum } & Maksimum \\
\hline KR & \multicolumn{2}{|c|}{0,0388} & \multicolumn{2}{|c|}{0,0222} & \multicolumn{2}{|c|}{0,0319} & \multicolumn{2}{|c|}{0,0159} & 0,1787 \\
\hline KTV & \multicolumn{2}{|c|}{0,7269} & \multicolumn{2}{|c|}{0,0522} & \multicolumn{2}{|c|}{0,7284} & \multicolumn{2}{|c|}{0,6047} & 0,8226 \\
\hline KRKTV & \multicolumn{2}{|c|}{0,0174} & \multicolumn{2}{|c|}{0,0061} & \multicolumn{2}{|c|}{0,0155} & \multicolumn{2}{|c|}{0,0087} & 0,0455 \\
\hline ÖTV & \multicolumn{2}{|c|}{0,1144} & \multicolumn{2}{|c|}{0,0215} & \multicolumn{2}{|c|}{0,1127} & \multicolumn{2}{|c|}{0,0776} & 0,1731 \\
\hline SYR & \multicolumn{2}{|c|}{0,1484} & \multicolumn{2}{|c|}{0,0200} & \multicolumn{2}{|c|}{0,1449} & \multicolumn{2}{|c|}{0,1154} & 0,2233 \\
\hline NKPGTV & \multicolumn{2}{|c|}{0,0281} & \multicolumn{2}{|c|}{0,0137} & \multicolumn{2}{|c|}{0,0277} & \multicolumn{2}{|c|}{0,0079} & 0,0621 \\
\hline GGVTV & \multicolumn{2}{|c|}{0,7546} & \multicolumn{2}{|c|}{0,0535} & \multicolumn{2}{|c|}{0,7625} & \multicolumn{2}{|c|}{0,6480} & 0,8879 \\
\hline LNTV & \multicolumn{2}{|c|}{16,0401} & 0,7 & 88 & 16,0 & 675 & 14, & 5495 & 17,3278 \\
\hline Panel B & bariyle & Değiș & lere İliș & sin Ort & malar & & & & \\
\hline & 2006 & 2007 & 2008 & 2009 & 2010 & 2011 & 2012 & 2013 & 2014 \\
\hline KR & 0,02 & 0,02 & 0,02 & 0,04 & 0,04 & 0,03 & 0,02 & 0,02 & 0,02 \\
\hline KTV & 0,71 & 0,72 & 0,78 & 0,70 & 0,73 & 0,72 & 0,75 & 0,71 & 0,66 \\
\hline KRKTV & 0,01 & 0,01 & 0,01 & 0,02 & 0,02 & 0,02 & 0,02 & 0,02 & 0,01 \\
\hline ÖTV & 0,09 & 0,14 & 0,13 & 0,12 & 0,11 & 0,10 & 0,10 & 0,09 & 0,08 \\
\hline SYR & 0,13 & 0,21 & 0,18 & 0,16 & 0,14 & 0,14 & 0,13 & 0,15 & 0,14 \\
\hline NKPGTV & 0,03 & 0,03 & 0,04 & 0,03 & 0,03 & 0,02 & 0,03 & 0,02 & 0,02 \\
\hline GGVTV & 0,71 & 0,72 & 0,78 & 0,75 & 0,78 & 0,78 & 0,77 & 0,77 & 0,73 \\
\hline LNTV & 17,70 & 15,00 & 15,30 & 15,60 & 15,80 & 16,00 & 16,20 & 16,50 & 16,80 \\
\hline
\end{tabular}

2006-2014 yılları arasında Türkiye'de faaliyet gösteren ve analize dahil edilen katııım bankalarına ilișkin kredi riski ve kredi riskini etkileyen değișkenler ile bu değișkenlerin özelliklerini gösteren tanımlayıcı istatistikler tabloda gösterilmektedir. Katılım bankalarına özgü bağımlı ve bağımsız değișkenler \%1 düzeyinde winsorize edilmiștir. Bütün değișkenler Tablo 1'de tanımlandığı gibidir.

Çalıșmada kullanılan değișkenlerin yıllar itibariyle ortalama değerleri Tablo 2 Panel B'de sunulmaktadır. Yıllar itibariyle ince- 
lendiğinde, kredi riskinin 2008 küresel ekonomik krizi sonrasında 2009 ve 2010 yıllarında en yüksek düzeye (\%4) çıktığı görülmektedir. Katılım bankalarının sundukları kredilerin toplam varlıklar içindeki payının da 2008 yılında en yüksek değerine (\%78); 2014 yılında ise, en düșük değerine (\%66) ulaștığı görülmektedir. Özkaynakların toplam varlıklara oranı ise, 2007 yılından sonra giderek azalmaya bașlamıștır. Sermaye yeterlilik rasyosu da yıllar itibariyle Basel II Kriterleri'nde belirtilen \%8 oranının altına düșmemiș ve hatta bu oranın oldukça üzerinde bir seyir izlemiștir.

\section{Ampirik Bulgular}

Çalıșmada ilk olarak analizde kullanılacak değișkenlerin durağanlığı panel birim kök testleri ile incelenmiștir. Panel birim kök testi sonuçları Tablo $3^{\prime}$ te gösterilmektedir ${ }^{8}$.

\section{Tablo 3: Değișkenlere ilișkin Panel Birim Kök Testi Sonuçları}

\begin{tabular}{lccc}
\hline Değișkenler & LLC & IPS & ADF-Fisher \\
\hline Panel A: Düzey & & & \\
\hline KR & 1,9366 & 2,0898 & 3,3040 \\
KTV & $-0,8177$ & $-0,5619$ & 8,1716 \\
KRKTV & $-0,4377$ & $-1,0073$ & 10,5140 \\
ÖTV & 0,1575 & $-0,0225$ & 5,6972 \\
SYR & $-1,3750^{*}$ & $-2,3985^{* * *}$ & $19,6847^{* *}$ \\
NKPGTV & 8,4838 & 0,0732 & 4,4294 \\
GGVTV & $-2,5763^{* * *}$ & $-1,7962^{* *}$ & $14,2914^{*}$ \\
LNTV & $-0,1673$ & 2,2751 & 1,7813 \\
\hline Panel B: Birinci Fark & & & \\
\hline KR & $-6,4637^{* * *}$ & $-6,4516^{* * *}$ & $52,3592^{* * *}$ \\
KTV & $-9,7377^{* * *}$ & $-9,7643^{* * *}$ & $86,5443^{* * *}$ \\
KRKTV & $-5,0858^{* * *}$ & $-4,6952^{* * *}$ & $45,7735^{* * *}$
\end{tabular}

8 Tablo 3'te sabitli modeller için elde edilen birim kök testi sonuçları sunulmaktadır (sabitsiz ve sabitli-trendli modeller yazardan istek üzerine gönderilir). Serilerin düzeyde birim kök içermedikleri anlașıldığında, birinci farkları ya da ikinci farkları için tekrar birim kök testi yapılmamıștır. 


\begin{tabular}{lccc} 
ÖTV & $-9,5206^{* * *}$ & $-9,1448^{* * *}$ & $78,9623^{* * *}$ \\
SYR & - & - & - \\
NKPGTV & 50,9590 & $-1,6084^{*}$ & $14,1300^{*}$ \\
GGVTV & - & - & - \\
LNTV & $-8,4896^{* * *}$ & $-10,1635^{* * *}$ & $87,8706^{* * *}$ \\
\hline Panel C: ikinci Fark & & - & - \\
\hline KR & - & - & - \\
KTV & - & - & - \\
KRKTV & - & - & - \\
ÖTV & - & - & - \\
SYR & - & $-51,6860^{* * *}$ & - \\
NKPGTV & $-68,0421^{* * *}$ & - & - \\
GGVTV & - & - & $-3642^{* * *}$ \\
LNTV & - & - & -
\end{tabular}

Tabloda LLC, Levin, Lin ve Chu panel birim kök testini; IPS, Im, Peseran ve Shin panel birim kök testini; ADF-Fisher ise, Genelleștirilmiș Dickey Fuller panel birim kök testini ifade etmektedir. Bütün testlerde uygun gecikme uzunlukları Schwarz bilgi kriterine göre belirlenmiștir. Hipotezler; $\mathrm{H}_{0}$ : Seride birim kök vardır, $\mathrm{H}_{1}$ : Seride birim kök yoktur șeklinde olușturulmuștur. Bütün değișkenler Tablo 1'de tanımlandığı gibidir. ${ }^{* * *},{ }^{* *},{ }^{*}$ sırasıyla \%1, \%5 ve \%10 düzeyinde anlamlılığı göstermektedir.

Tablo 3 'te yer alan birim kök test sonuçları incelendiğinde, bazı değișkenlerin düzeyde durağan olduğu, bazılarının ise birinci veya ikinci farkı alındığında durağan hale geldiği görülmektedir. Tablo 3'e göre, SYR ve GGVTV serilerinin düzeyde; KR, KTV, KRKTV, ÖTV, LNTV serilerinin birinci farkları alındığında; NKPGTV serisinin ise, ikinci farkının alınmasıyla durağan olduğu görülmektedir. Durağan olmayan seriler ile ekonometrik bir analizin yapılması, sahte regresyon olarak adlandırılan yanıltıcı bir sonuca neden olacağından, tüm değișkenler durağan hale getirildikten sonra analize dahil edilmiștir. Analize dahil edilen farkları alınmıș yeni serilere ilișkin tanımlayıcı istatistikler Tablo 4 'te gösterilmektedir. 


\section{Tablo 4: Farkı Alınmıș Serilerin Tanımlayıcı İstatistikleri}

\begin{tabular}{lccccc}
\hline Değișkenler & Ortalama & Std. Sapma & Medyan & Minumum & Maksimum \\
\hline KR & 0,0006 & 0,0083 & $-0,0002$ & $-0,0108$ & 0,0734 \\
KTV & $-0,0003$ & 0,0327 & $-0,0008$ & $-0,1230$ & 0,1050 \\
KRKTV & 0,0001 & 0,0029 & $-0,0001$ & $-0,0073$ & 0,0216 \\
ÖTV & $-0,0002$ & 0,0100 & $-0,0014$ & $-0,0242$ & 0,0535 \\
NKPGTV & 0,0000 & 0,0313 & $-0,0002$ & $-0,0665$ & 0,0668 \\
LNTV & 0,0613 & 0,0603 & 0,0681 & $-0,2281$ & 0,2365 \\
\hline
\end{tabular}

NKPGTV değișkeni ikinci farkı alındıktan sonra, tabloda sunulan diğer tüm değișkenler ise, birinci farkı alındıktan sonra durağan hale gelmiștir. SYR ve GGVTV değișkenleri düzeyde durağandır ve bu değișkenler ilișkin tanımlayıcı istatistikler Tablo 2 'de yer almaktadır. Bütün değișkenler Tablo 1'de tanımlandığı gibidir.

Panel veri regresyonunda ilk olarak Model (4)'ün tek yönlü mü iki yönlü mü olduğu araștırılmıșıır. Bu nedenle hatalarda sabit etkilerin varlığı Model (1)'de verilen $\mathrm{F}_{\mathrm{O} \text { os }}$ istatistiği ile test edilmiștir. $\mathrm{F}_{\mathrm{O} \text { ss }}$ istatistiğine ait sonuçlar Tablo $5^{\prime}$ te sunulmaktadır.

\section{Tablo 5: Sabit Etkiler Modeli F Testi Sonuçları}

\begin{tabular}{lccc}
\hline & $\mathrm{H}_{1}$ & $\mathrm{H}_{2}$ & $\mathrm{H}_{3}$ \\
\hline F-değeri & 2,3369 & 1,1276 & 2,4416 \\
p-değeri & 0,0006 & 0,3406 & 0,0004 \\
\hline
\end{tabular}

$H_{1}: \mu=0, \lambda=0, H_{2}: \mu=0 \mid \lambda \neq 0$ ve $H_{3}: \lambda=0 \mid \mu \neq 0$

Tablo $5^{\prime}$ te iki yönlü sabit etkinin olmadığını ileri süren $\mathrm{H}_{1}: \mu$ $=0, \lambda=0$ hipotezi \% 1 anlamlılık düzeyinde tüm modeller için reddedilmektedir. Bu nedenle, modellerde en az tek yönlü bir sabit etkinin var olması beklenmektedir ve bu nedenle tüm modeller için $\mathrm{H}_{2}: \mu=0 \mid \lambda \neq 0$ ve $\mathrm{H}_{3}: \lambda=0 \mid \mu \neq 0$ tek yönlü hipotezleri de test edilmiștir. Test sonuçlarına göre, $\mathrm{H}_{2}$ hipotezi reddedilemezken, $\mathrm{H}_{3}$ hipotezi \% 1 anlamlılık düzeyinde reddedilmektedir. Bu sonuçlar, zaman boyutunda bir sabit etkinin varlığını göstermektedir.

Model (4)'ün hatalarında değișen varyansın varlığını tespit etmek için $L M$ testi kullanılmaktadır. $L M$ testi sonucunda, $\chi_{2}^{2}=47,5432$ (p-değeri=0,0000) ile sabit varyansın varlı̆ııı ifade eden $\mathrm{H}_{0}$ hipotezi \% 1 anlamllık düzeyinde reddedilmiștir. Bu nedenle, hatalarda değișen varyans probleminin varlığı kabul edil- 
miș ve değișen varyans problemini ortadan kaldırmak için White (1980)'nin değișen varyansa uyumlu kovaryans matris tahmincisi kullanılmıștır.

Katılım bankalarında kredi riskini etkileyen faktörleri tespit etmek için Model (4) tek yönlü (zaman) sabit etkiler yöntemi ile tahmin edilmiștir. Kredi riski ile bankalara özgü yedi bağımsız değișken arasındaki ilișkileri gösteren modelin sonuçları Tablo 6'da özetlenmektedir. Katılım bankalarının kredi riskindeki değișmelerin, bağımsız değișkenler tarafından açıklanma oranı $\left(R^{2}\right) \% 81,4^{\prime}$ tür. Model, \% 1 düzeyinde istatistiksel olarak anlamlıdır (F-istatistiği= 10,3670). Tablo 6'daki sonuçlar incelendiğinde, modele dahil edilen toplam yedi değișkenden, sadece üçünün istatistiksel olarak anlamlı, diğerlerinin ise istatistiksel olarak anlamsız olduğu görülmektedir. İstatistiksel olarak anlamlı bulunan değișkenler;KTV (Toplam Krediler/Toplam Varlıklar), KRKTV (Özel Karșilıklar/Toplam Varlıklar) ve LNTV'dir (Toplam Varlıkların Doğal Logaritması). KTV değișkenin katsayısının ișareti negatiftir ve \%1 düzeyinde anlamlıdır $\left(\beta_{1}=-0,0589\right.$ ve t-istatistiği $\left.=-2,8730\right)$. Bu bulgu, kredilerin toplam varlıklar içindeki payının arttıkça, kredi riskinin de artacağı yönündeki beklentilerle uyușmamaktadır. Krediler ile ilgili bu bulgu, katılım bankalarının toplam varlıkları içindeki kredilerin payını artırarak, kredi risklerini düșürebileceklerini göstermektedir. Bu istatistiksel olarak anlamlı negatif sonuç, Rahman ve Shamini (2010) ve Misman ve diğerleri, 2013'ün Malezya'da faaliyet gösteren İslami bankalar için elde etmiș oldukları sonuçlar ile tutarlılık göstermektedir. Misman ve diğerleri (2013), bu durumun birkaç nedenden kaynaklanabileceğini ileri sürmektedir. Yazarlar, İslami bankaların sunmuș oldukları farklı türdeki kredilerin bankalara bir çeșitlendirme sağladığını ve kredi verme sürecinde bu bankaların çok sıkı bir inceleme yaptığını vurgulamaktadır.

KRKTV değișkeninin katsayısı beklenildiği gibi pozitiftir ve $\% 1$ düzeyinde istatistiksel olarak anlamlıdır $\left(\beta_{2}=1,7243\right.$ ve t-istatistiği $=4,2257)$. Bu durum, katılım bankalarının geri ödenmeme riski tașıyan kredilere karșı ayırdıkları özel karșılıkların toplam varlıklar içindeki payının arttıkça, kredi risklerinin de artacağını göstermektedir. Bir bașka ifadeyle katılım bankalarının sunmuș 
oldukları kredilerin kalitesinin düșük seviyelerde olması, bu kredilerin temerrüt olasılığını artırarak kredi riskine neden olmaktadır. Bu nedenle katılım bankaları kredi risklerini düșürmek istiyorlarsa, kullandırdıkları kredilerin kalitesini artırmaya çalıșmalıdır. Bu bulgu, literatürde yer alan diğer çalıșmalardan elde edilen bulguları destekler niteliktedir. (Ahmet ve diğerleri, 1999; Eng ve Nabar, 2007; Misman ve diğerleri, 2013)

ÖTV değișkeninin ya da diğer bir ifadeyle sermaye tamponunun kredi riski üzerindeki etkisi beklenenin aksine negatif değil, pozitif bulunmuștur $\left(\beta_{3}=0,0821\right)$. Bu durum, katılım bankalarının sermaye tamponunu arttırsalar bile kredi riskini azaltamayacaklarını göstermektedir. Bu bulgu,Misman ve diğerleri (2013)'ün çalıșmalarında elde ettikleri bulgular ile tutarlıdır. Ancak, yazarlar çalıșmalarında, sermaye tamponunun katsayısını bazı modeller için istatistiksel olarak anlamlı bulmușken, bu çalıșmada katsayı istatistiksel olarak anlamlı bulunamamıștır (t-istatistiği $=1,1922$ ). Misman ve diğerleri (2013) bu pozitif ișaretin, yüksek ÖTV'li İslami bankaların düșük ÖTV'li İslami bankalara göre daha yüksek kredi riskine sahip olduklarını ișaret ettiğini ifade etmektedir. Ayrıca yazarlara göre bu sonuç, yüksek özsermayeli İslami bankaların potansiyel bir kayıp durumunda yeterli sermaye tamponuna sahip oldukları inancıyla daha riskli kredileri kullandırabildiklerini göstermektedir. Diğer taraftan Abedifar ve diğerleri (2013) çalıșmalarında, sermaye tamponunun katsayısını negatif bulmușlar, ancak istatistiksel olarak anlamlı olmadığı sonucuna varmıșlardır. Rahman ve Shahimi (2010) ise, Malezya'da faaliyet gösteren İslami bankaların sermaye tamponu ile kredi riski arasında istatistiksel olarak anlamlı negatif bir ilișkinin olduğunu göstermektedir. Katılım bankalarının sermayelerinin kredi riski üzerindeki etkisini gösteren bir diğer önemli değișken de sermaye yeterlilik rasyosudur (SYR). SYR ile kredi riski arasındaki ilișkiyi inceleyen ampirikçalıșmaların sonuçları birbirinden farklıdır. Bazı çalıșmalar SYR'nin kredi riski ile arasında negatif bir ilișkisinin olduğunu belirtirken (Berger ve DeYoung, 1997; Misman ve diğerleri, 2013), diğerleri ise bu iki değișken arasında pozitif bir ilișkini olduğunu ileri sürmektedir (Ahmad ve Ariff, 2007).Çalıșmamızda SYR değișkeninin 
katsayısının ișareti pozitif olsa da bu katsayı istatistiksel olarak anlamsızdır $\left(\beta_{4}=0,0210\right.$ ve t-istatistiği $\left.=0,8793\right)$.

\section{Tablo 6: Katılım Bankalarının Kredi Riskini Belirleyen Faktörler}

\begin{tabular}{lcccc}
\hline & Katsayı & Std. Hata & t-istatistiği & p-değeri \\
\hline C & $-0,0028$ & 0,0063 & $-0,4428$ & 0,6589 \\
KTV & $-0,0589^{* * *}$ & 0,0205 & $-2,8730$ & 0,0050 \\
KRKTV & $1,7243^{* * *}$ & 0,4081 & 4,2257 & 0,0001 \\
ÖTV & 0,0821 & 0,0689 & 1,1922 & 0,2361 \\
SYR & 0,0210 & 0,0239 & 0,8793 & 0,3815 \\
NKPGTV & 0,1675 & 0,1205 & 1,3906 & 0,1676 \\
GGVTV & 0,0040 & 0,0075 & 0,5326 & 0,5956 \\
LNTV & $-0,0475^{* *}$ & 0,0214 & $-2,2178$ & 0,0289 \\
& & & & \\
R2 & 0,8136 & & & \\
Durbin-Watson & 1,8833 & & & \\
İstatistiği & $10,3670^{* * *}$ & & & \\
F-ístatistiği \\
Gözlem Sayısı & 136 & & & \\
\hline
\end{tabular}

Katılım bankalarının kredi riskini etkileyen faktörleri belirlemek için așağıdaki tek yönlü (zaman) sabit etkiler panel veri regresyon modeli kullanılmıștır. Modeldeki değișen varyans problemi White (1980)'nin değișen varyansa uyumlu kovaryans matris tahmincisi kullanılarak giderilmiștir. $\mathrm{KR}_{\text {it }}=\beta_{0}+\beta_{1} \mathrm{KTV}_{\text {it }}+\beta_{2} \mathrm{KRKTV}_{\text {it }}+\beta_{3}$ ÖTV it $+\beta_{4} \mathrm{SYR}_{\text {it }}+\beta_{5} \mathrm{NKPGTV}_{\text {it }}+\beta_{6} \mathrm{GGVTV}_{\text {it }}+\beta_{7} \mathrm{LNTV}_{\text {it }}+\varepsilon_{\text {it }}$ Modelde kullanılan bütün değișkenler Tablo 1'de tanımlandığı gibidir. ${ }^{* * *},{ }^{* *},{ }^{*}$ sırasıyla \% 1, \%5 ve \%10 düzeyinde anlamlılı̆ı göstermektedir.

Ticari bankalarda net faiz mariı, İslami bankalarda ise net kar payı geliri bankaların kredi politikalarını etkileyebilmektedir. Angbazo (1997), bir bankanın net faiz mariının azalması durumunda o bankanın daha riskli kredi taleplerini kabul edeceğini ve böylece dolaylı olarak kredi riskini artıracağını ileri sürmektedir. Bu bağlamda yazar, düșük net faiz marjına sahip bankaların kredi riskinin daha yüksek sevilerde olma eğilimi olduğunu ifade etmektedir. Öte yandan literatürde yer alan diğer çalıșmalar net faiz mariı ile kredi riski arasında pozitif bir ilișkinin olduğunu göstermektedir (Rahman ve Shahimi, 2010). Bu çalıșmada net kar payı geliri toplam varlıklar oranının (NKPGTV) katsayısının ișareti pozitiftir, ancak katsayı istatistiksel olarak anlamsızdır $\left(\beta_{5}=\right.$ $0,1675$ ve t-istatistiğ $i=1,3906)$. 
Katılım bankalarına ait gelir getiren varlıklar (GGVTV), krediler kalemine finansal varlıklar ve yatırımların eklenmesiyle elde edilmiștir. Literatürde GGVTV değișkeninin katsayısının negatif olması beklenmektedir. Ancak, gelir getiren varlıkların etkin bir șekilde yönetilmemesi durumunda, daha yüksek bir kredi riskine de neden olacağı belirtilmektedir (Ahmad ve Ahmad, 2004).Çalıșmada GGVTV değișkeninin katsayısının ișareti beklenenin aksine pozitifftir ancak istatistiksel olarak anlamlı değildir $\left(\beta_{6}=0,0040\right.$ ve t-istatistiği $=0,5326$ ).

Katılım bankalarının büyüklüğü ile kredi riski arasında negatif bir ilișkinin olması beklenmektedir. Çalıșmada toplam varlıkların doğal logaritması olarak ölçülen büyüklük değișkeninin (LNTV) katsayısının ișareti beklenildiği gibi negatiftir ve \%5 düzeyinde istatistiksel olarak anlamlıdır $\left(\beta_{7}=-0,0475\right.$ ve t-istatistiği $\left.=-2,2178\right)$. Saunders ve diğerleri (1990) ve Misman ve diğerleri (2013), bu negatif ilișkinin birkaç nedenden kaynaklanabileceğini ileri sürmektedir. Yazarlara göre, büyük bankalar varlıklarına ilișkin riskleri çeșitlendirmede küçük bankalara göre daha bașarılı olabilmekte ve bu nedenle daha riskli kredilerin bankaya olan olumsuz etkilerini ortadan kardırabilmektedir. Ayrıca yazarlar,batmasına izin verilmeyecek kadar büyük banka veya șirket ilkesi (too big to fail) doğrultusunda yatırımcıların düzenleyici ve denetleyici kurumlar tarafından büyük bankaların iflas etmesine göz yumulmayacağına inandıklarını ileri sürmektedir.

\section{Sonuç}

Bu çalıșmada, 2006-2014 yılları arasında Türkiye'de faaliyet gösteren katılım bankalarının kredi riskini belirleyen faktörler panel veri regresyon modeli kullanılarak tespit edilmeye çalıșılmaktadır. Panel veri regresyon modeli tek yönlü (zaman) sabit etkiler yöntemi ile tahmin edilmiștir. Modelde kullanılan bankaya özgü faktörler katılım bankalarının kredi riskini \%81,4 düzeyinde açıklamaktadır. Çalıșmanın bulguları, Özel Karșılıklar/Toplam Varlıklar (KRKTV) faktörünün katılım bankalarının kredi riskiyle pozitif yönde ilișkili olduğunu göstermektedir. Bir bașka ifadeyle bu bulgu, katılım bankalarının geri ödenmeme riski tașıyan kredilere 
karșı ayırdıkları özel karșılıkların toplam varlıklar içindeki payının arttıkça, kredi risklerinin de artacağı anlamına gelmektedir. Diğer taraftan Toplam Krediler/Toplam Varlıklar (KTV) ve Toplam Varlıkların Doğal Logaritması (LNTA) faktörlerinin katılım bankalarının kredi riskiyle negatif yönde ilișkili olduğu bulunmuștur. Bu bulgular ise, kredilerin toplam varlıklar içindeki payının arttıkça ya da katılım bankalarının varlık büyüklüğünün artıkça kredi risklerinin azalacağını ifade etmektedir. Bu bağlamda çalıșma, katılım bankalarının kredi riskini yönetirken hangi içsel faktörleri dikkate almaları gerektiğini göstermesi açısından önemlidir. Bu içsel faktörleri dikkate alarak kredi riskini yöneten katılım bankalarının performanslarının da bu durumdan olumlu yönde etkileneceği düșünülmektedir.

Çalıșmada katılım bankalarının kredi riskini belirleyen faktörler ortaya koyulurken sadece bankaya özgü değișkenler modele dahil edilmiștir. Bu bağlamda gelecekte yapılacak çalıșmalar, modele bankaya özgü değișkenlerin yanında makroekonomik değișkenleri de ekleyebilir. Ayrıca ileride gerçekleștirilecek çalıșmalarda, ticari bankalar ile katılım bankalarının kredi riskini belirleyen faktörler karșılaștırmalı olarak incelenebilir. 


\section{KAYNAKLAR}

Abedifar, P., P. Molyneux, ve A. Tarazi. 2013. Risk in Islamic Banking. Review of Finance 17(6):2035-2096.

Ahmad, N. H. ve M. Ariff. 2007. Multi-country study of bank credit risk determinants. The International Journal of Banking and Finance 5(1):135-152.

Ahmad, N. H. ve S. N. Ahmad. 2004. Key factors influencing credit risk of Islamic bank: A Malaysian case. The Journal of Muamalat and Islamic Finance Research 1(1):65-80.

Ahmed, A. S., Carolyn T. ve Shawn T. 1999. Bank loan loss provisions: a reexamination of capital management, earnings management and signaling effects. Journal of Accounting and Economics 28(1): 1-25.

Ahmed, H. ve T. Khan. 2007. Risk management in Islamic banking. M. K. Hassan ve M. K. Lewis (eds.), Handbook of Islamic banking (ss. 144-158). Cheltenham, UK: Edward Elgar.

Ahmed, N., M. F. Akhtar ve M. Usman. 2011. Risk management practices and Islamic banks: An emprical investigation from Pakistan. Interdisciplinary Journal of Research in Business 1 (6):50-57.

Ali, A. ve S. P. Ghauri. 2013. Global crisis and credit risk management by banks: A comparative study of banks in Pakistan. International Journal of Business and Economics Research 2(6):158-168.

Al-Wesabi, H. A. H. ve N. H. Ahmad. 2013. Credit risk of Islamic banks in GCC countries. The International Journal of Banking and Finance 10(2): 1. 24.

Angbazo, L. 1997. Commercial bank net interest margins, default risk, interestrate risk, and off-balance sheet banking. Journal of Banking and Finance 21 (1):55-87.

Berger, A. N. ve R. DeYoung. 1997. Problem loans and cost efficiency in commercial banks. Journal of Banking and Finance $21(6): 849-870$.

Cebenoyan, A. S. ve P. E. Strahan. 2004. Risk management, capital structure and lending at banks. Journal of Banking and Finance 28(1):19-43.

Çelik, S. ve Y. D. Akarım. 2012. Likidite riski yönetimi: Panel veri analizi ile IMKB bankacilık sektörü üzerine ampirik bir uygulama. Eskișehir Osmangazi Üniversitesi Sosyal Bilimler Dergisi 13(1): 1-17.

Colquitt, J. 2007. Credit risk management: How to avoid lending disasters and maximize earnings. $3^{\text {rd }}$ edition. USA: McGraw-Hill.

Cornett, M. M., J. J. McNutt, P. E. Strahan ve H. Tehranian. 201 1. Liquidity risk management and credit supply in the financial crisis. Journal of Financial Economics 101(2):297-312. 
Eng, L. L. ve S. Nabar. 2007. Loan loss provisions by banks in Hong Kong, Malaysia and Singapore. Journal of International Financial Management and Accounting 18(1):18-38.

Erlat, H. 2011 . Panel data: a selective survey. Unpublished Lecture Notes, Department of Economics, Middle East Technical University. Ankara.

Ferhi, A. ve R. Chkoundali. 2015. Credit risk and efficiency: Comparative study between Islamic and conventional banks during the current crisis. Journal of Behavioral Economics, Finance, Entrepreneurship, Accounting and Transport 3(1):47-56.

Fiordelisi, F., D. Marques-lbanez ve P. Molyneux. 2011 . Efficiency and risk in European banking. Journal of Banking and Finance 35(5):1315-1326.

Greene, W. H. 2003. Econometric analysis. $5^{\text {th }}$ edition. Upper Saddle River, New Jersey: Prentice Hall.

Griffiths, W. E., R. C. Hill, and G. C. Lim. 2012.Using EViews for principles of econometrics. $4^{\text {th }}$ edition. New York: John Wiley \& Sons Ltd.

How, J. C. Y., M. A. Karim ve P. Verhoeven. 2005. Islamic financing and bank risks: The case of Malaysia. Thunderbird International Business Review 47(1):75-94.

Im, K. S., M. H. Pesaranve Y. Shin. 2003. Testing for unit roots in heterogeneous panels. Journal of Econometrics 115:53-74.

Khan, T. ve H. Ahmed. 2001. Risk management: An analysis of issues in Islamic financial industry (Occasional Paper). Islamic Research and Teaching Institute. Jeddah- Saudi Arabia.

Korkmaz, T., B. Yıldız, ve R. İ. Gökbulut. 2010. FVFM'nin IMKB ulusal 100 endeksindeki geçerliliğinin panel veri analizi ile test edilmesi. İstanbul Üniversitesi İșletme Fakültesi Dergisi 39(1):95-105.

Levin, A., C. Lin ve J. C. Chu. 2002. Unit root tests in panel data: asymptotic and finite-sample properties. Journal of Econometrics 108(1):1-24.

Masood, O., H. A. Suwaidive P. D. P. Thapa. 2012. Credit risk management: A case differentiating Islamic and non-Islamic banks in UAE. Qualitative Research in Financial Markets 4(2/3):197-205.

Misman, F. N., W. Lou ve I. Bhatti. 2013. The determinants of credit risk of Islamic banks in Malaysia: A panel study. $3^{\text {rd }}$ Annual International Conference on Accounting and Finance (AF 2013), Bangkok, Thailand.

Nursechafia, M. A. 2014. The susceptibility of Islamic banks' credit risk towards macroeconomic variables. Journal of Islamic Finance 3(1):23-37.

Nurul, K., A. Worthington ve R. Gupta. 2014. Comparative credit risk in Islamic and conventional bank. Pacific-Basin Finance Journal 34:327-353. 
Okłay, S. ve H. Temel. 2007. Basel II kriterleri ekseninde ticari bankalarda kredi riski yönetiminin karșılaștırılmasına yönelik bir saha çalıșması. ZKÜ Sosyal Bilimler Dergisi 3(6), 163-185.

Polat A. 2009. Finansal yenilik ve açıımları ile katılım bankacılığı. İstanbul: Türkiye Katılım Bankaları Birliği.

Rahman, A. A. ve S. Shahimi. 2010. Credit risk and financing structure of Malaysian Islamic banks. Journal of Economic Cooperation and Development $31(3): 83-105$.

Saunders, A., E. Strockve N. G. Travlos. 1990. Ownership structure, deregulation, and bank risk taking. The Journal of Finance 45(2):643-654.

TKBB (Türkiye Katılım Bankaları Birliği). 2014. Katılım bankaları 2014. http:// www.tkbb.org.tr/documents/KATILIM_2014_TR_final.pdf (18.12.2015).

Tunay, B. K. ve M. Silpar. 2006. Türk Ticari Bankacılık Sektöründe Karlılığa Dayalı Performans Analizi-I. Araștırma Tebliğleri Serisi, Türkiye Bankalar Birliği.

Türker, H. (2010). İslami finans sisteminde finansal aracılık: Dünyadaki gelișmeler ve sermaye piyasasının geliștirilmesi açısından Türkiye için öneriler. Yeterlilik Etüdü, Sermaye Piyasası Kurulu Aracılık Faaliyetleri Dairesi, Ankara.

White, H. 1980. A heteroscedasticity-consistent covariance matrix estimator and a direct test for heteroscedasticity. Econometrica 48:817-838.

Wooldridge, J. M. 2002. Econometric analysis of cross section and panel data. Cambridge, Massachusetts: The MIT Press.

Yaslıdağ, B. 2007. Kredi Derecelendirme Sistemi. İstanbul: Literatür Yayıncılık. Yerdelen Tatoğlu, F. 2012. Panel Veri Ekonometrisi. İstanbul: Beta Yayıncılık.

Yıldız, M. E., A. Yalama ve G. Sevil. 2009. Sermaye yapısı teorilerinin geçerliliğinin test edilmesi: Panel veri analizi kullanılarak IMKB - imalat sektörü üzerinde ampirik bir uygulama. İktisat İșletme ve Finans 24(278):25-45. 